\title{
PENGARUH CAPITAL ADEQUACY RATIO (CAR), BOPO DAN NON PERFORMING LOAN (NPL) TERHADAP KINERJA KEUANGAN PERBANKAN DI INDONESIA
}

\author{
Anggria Maya Matindas \\ Sifrid S. Pangemanan \\ David P.E. Saerang \\ Fakultas Ekonomi dan Bisnis Magister Akuntansi \\ Universitas Sam Ratulangi Manado \\ email: anggria13@gmail.com
}

\begin{abstract}
This study aimed to determine the effect of the Capital Adequacy Ratio (CAR), ROA and NonPerforming Loans (NPLs) of the return on assets (ROA) banking companies listed in Indonesia Stock Exchange 2008-2010 period. Data obtained from the Financial Report issued by Bank Indonesia with the time period of 2008 to 2010. The population of this study were 28 companies and a total sample of 22 companies with a purposive sample passing phase. Analysis techniques will be used in this research is regression to obtain a comprehensive picture of the relationship between one variable with another variable. The results showed that the variable Capital Adequacy Ratio (CAR) is not significant and has a negative relationship to the ability of return of assets (ROA), ROA indicates that the variable ROA ROA significant effect on the banking company. While the Non Performing Loan (NPL) had no significant effect on ROA banking company. The result is expected that the variable Capital Adequacy Ratio (CAR), ROA, and Non-Performing Loans (NPLs) could be considered by the bank management in managing the company to improve the performance of the company.
\end{abstract}

Keywords: CAR, ROA, NPLs, BOPO, and Bank

\section{PENDAHULUAN}

\subsection{Latar Belakang}

Bank merupakan lembaga keuangan yang menjadi tempat bagi perusahaan, badan-badan pemerintah dan swasta, maupun perorangan menyimpan dana-dananya. Bank adalah lembaga keuangan yang fungsi utamanya menyediakan jasa intermediasi \& jasa keuangan lainnya kepada perusahaan dan rumah tangga, dengan tujuan untuk memaksimumkan kekayaan pemilik. Resiko yang mungkin terjadi dalam kegiatan perbankan dapat menimbulkan kerugian bagi bank jika tidak dideteksi serta tidak dikelolah sesuai dengan prosedur. Untuk itu bank harus memahami dan mengenal resiko-resiko yang mungkin timbul dalam melaksanakan kegiatan usahanya. Resiko tidak harus selalu dihindari dari semua keadaan namun semestinya dikelolah secara baik tanpa harus mengurangi hasil yang ingin dicapainya.

Peranan perbankan sangat mempengaruhi kegiatan ekonomi suatu negara. Saat ini perkembangan di dunia perbankan sangat pesat serta tingkat persaingan yang tinggi dapat berpengaruh terhadap performa suatu bank. Semakin maju suatu negara maka semakin besar peranan perbankan dalam mengendalikan negara tersebut. Hal tersebut tampak dalam kegiatan pokok bank yang menerima simpanan dari masyarakat dalam bentuk tabungan, giro, deposito berjangka, dan memberikan kredit kepada pihak yang memerlukan dana. Adapun masalah yang ditimbulkan saat menjalankan usaha perbankan kredit macet hal ini dapat menyebabkan kinerja bank menurun. Dalam pemberian kredit bank di tuntut gara dapat memperoleh keuntungan yang besar sehingga dapat menutupi semua biaya-biaya yang ditimbulkan dalam kegiatan operasionalnya. Kredit yang diberikan kepada masyarakat sangat memberikan laba atau keuntungan yang 
besar bagi pihak bank. Oleh karena itu bank harus mengelolah dengan baik kredit yang diberikan agar tidak resiko yang akan dihadapi sangat kecil.

Penilaian kesehatan bank versi Bank Indonesia mengacu pada unsur-unsur Capital, Assets Quality, Management, Earning, Liquidity dan Sensitivity, sedangkan dalam penelitian ini menerapkan rasio- rasio keuangan yang umum digunakan untuk mengukur kinerja keuangan bank. Alasan dipilihnya Return On Assets (ROA) sebagai variabel dependen dengan alasan bahwa ROA digunakan untuk mengukur efektifitas perusahaan dalam menghasilkan keuntungan dengan memanfaatkan aktiva yang dimilikinya. ROA merupakan rasio antara laba sesudah pajak terhadap total assets. Semakin besar ROA menunjukkan kinerja perusahaan semakin baik, karena tingkat pengembalian (return) semakin besar. ROA juga merupakan perkalian antara faktor net income margin dengan perputaran aktiva. Net Income Margin menunjukkan kemampuan memperoleh laba dari setiap penjualan yang diciptakan oleh perusahaan, sedangkan perputaran aktiva menunjukkan seberapa jauh perusahaan mampu menciptakan penjualan dari aktiva yang dimilikinya. Apabila salah satu dari faktor tersebut meningkat (atau keduanya), maka ROA juga akan meningkat. Alasan dipilihnya industri perbankan karena kegiatan bank sangat diperlukan bagi lancarnya kegiatan perekonomian di sektor riil. Sektor riil tidak akan dapat berkinerja dengan baik apabila sektor moneter tidek bekerja dengan baik.

Variabel-variabel tersebut antara lain yaitu Capital Adequacy Ratio (CAR), Biaya Operasi dibanding Pendapatan Operasi (BOPO), Non Performing Loan (NPL). Oleh karena itu perlu diuji kembali konsistensi dari variable-variabel tersebut dalam mempengaruhi kinerja bank.

\subsection{Rumusan Masalah}

Berdasarkan dari uraian tersebut, permasalahan yang akan dibahas dalam penelitian ini adalah :

1. Apakah Capital Adequacy Ratio (CAR) berpengaruh terhadap kinerja keuangan Bank yang diukur dengan Return On Asset (ROA) ?

2. Apakah BOPO berpengaruh terhadap kinerja keuangan Bank yang diukur dengan Return On Asset (ROA)?

3. Apakah Non Performing Loan (NPL) berpengaruh terhadap kinerja keuangan Bank yang diukur dengan Return On Asset (ROA)?

4. Variable-variabel manakah yang paling dominan mempengaruhi kinerja keuangan Bank yang diukur dengan ROA.

\subsection{Tujuan Penelitian}

Sesuai dengan permasalahan diatas maka tujuan dari penelitian ini adalah :

1. Untuk membuktikan seberapa besar pengaruh CAR, BOPO dan NPL terhadap kinerja keuangan bank yang diukur dengan ROA.

2. Untuk menganalisa variable-variabel manakah yang paling dominan berpengaruh terhadap kinerja keuangan bank yang diukur dengan ROA.

\subsection{Manfaat Penelitian}

Manfaat yang diharapkan dari penelitian ini adalah :

1. Untuk peneliti sebagai sarana untuk mengaplikasikan ilmu yang telah diperoleh selama menempuh pendidikan di Program Studi Magister Akuntansi Fakultas Ekonomi Universitas Sam Ratulangi lebih khusus lagi tentang pengaruh CAR, BOPO dan NPL terhadap kinerja keuangan Bank umum di Indonesia yang diukur dengan ROA.

2. Untuk dapat memberikan masukan bagi pihak Bank bahwa CAR, BOPO, dan NPL berpengaruh terhadap kinerja keuangan Bank.

3. Untuk penelitian selanjutnya kiranya hasil penelitian ini diharapkan dapat menjadi bahan pertimbangan, masukan dan acuan. 


\subsection{Tinjauan Pustaka}

Beberapa penelitian terdahulu yang digunakan sebagai bahan perbandingan dan refrensi untuk penelitian ini adalah sebagai berikut :

1. Wisnu Mawardi (2005) menganalisis pengaruh efisiensi operasi (BOPO), resiko kredit (NPL), resiko pasar (NIM), modal (CAR) terhadap kinerja keuangan (ROA) bank umum yang beroperasi di Indonesia yang mempunyai total assets kurang dari satu trilyun rupiah. Periodisasi data yang digunakan adalah tahun 1998 sampai dengan 2001. Hasil penelitian menunjukkan bahwa ada pengaruh negatif dan signifikan resiko kredit (NPL) terhadap kinerja keuangan (ROA), pengaruh positif dan signifikan resiko pasar (NIM) terhadap kinerja keuangan (ROA) serta pengaruh negatif dan signifikan efiensi operasi (BOPO) terhadap kinerja keuangan (ROA) dan tidak berpengaruh modal (CAR) terhadap kinerja keuangan ROA.

2. Penelitian Basran Desfian (2005) menguji pengaruh efisiensi, LDR dan CAR terhadap ROA. Hasil penelitiannya menyatakan bahwa efisiensi, LDR, CAR secara parsial signifikan terhadap ROA bank umum di Indonesia periode 2001-2003 dan secara bersama-sama berpengaruh terhadap ROA bank umum di Indonesia.

3. Penelitian yang dilakukan oleh Agus Suyono (2005) menguji pengaruh variabel CAR, BOPO, NIM, LDR, NPL, PLO, PK terhadap ROA. Hasil penelitiannya menunjukkan bahwa rasio-rasio keuangan bank terutama CAR, BOPO dan LDR mampu mempengaruhi ROA pada bank umum yang beroperasi di Indonesia pada periode 2001 sampai dengan 2003. Penelitian ini bertujuan menguji kembali variabel-variabel yang dalam penelitian terdahulu mempunyai pengaruh terhadap ROA yaitu antara lain CAR, NIM, NPL, BOPO dan LDR. Penelitian ini merupakan replikasi dari ketiga penelitian sebelumnya. Perbedaan penelitian ini dengan penelitian sebelumnya adalah pada variabel yang digunakan dan periodisasi data yaitu tahun 2005 .

\subsection{Hipotesa}

- $\mathrm{H}_{\mathrm{a} 1}$ : Capital Adequacy Ratio CAR berpengaruh terhadap ROA

- $\mathrm{H}_{01}$ : Capital Adequacy Ratio CAR tidak berpengaruh terhadap ROA.

- $\mathrm{H}_{\mathrm{a} 2}$ : Biaya Operasi Dibanding Dengan Pendapatan Operasi (BOPO) berpengaruh terhadap ROA

- $\mathrm{H}_{02}$ : Biaya Operasi Dibanding Dengan Pendapatan Operasi (BOPO) tidak berpengaruh terhadap ROA

- $\mathrm{H}_{\mathrm{a} 3}$ : non performing loan (NPL) berpengaruh terhadap ROA

- $\mathrm{H}_{03}$ : non performing loan (NPL) tidak berpengaruh terhadap ROA

\section{KERANGKA TEORITIS}

\subsection{Pengertian Perbankan}

Menurut Undang-undang Nomor 7 tahun 1992 tentang Perbankan sebagaimana telah diubah dengan Undang-undang nomor 10 tahun 1998 pengertian bank adalah badan usaha yang menghimpun dana dari masyarakat dalam bentuk simpanan dan menyalurkannya kepada masyarakat dalam bentuk kredit dan atau bentuk-bentuk lainnya dalam rangka meningkatkan taraf hidup rakyat banyak. Sedangkan Bank Umum adalah bank yang bertugas melayani seluruh jasa-jasa perbankan dan melayani segenap lapisan masyarakat, baik masyarakat perorangan maupun lembaga-lembaga lainnya. Bank umum juga dikenal dengan nama bank komersil dan dikelompokan kedalam 2 jenis yaitu: bank umum devisa dan bank umum non devisa. Bank umum yang berstatus devisa memiliki produk yang lebih luas daripada bank yang berstatus non devisa. Bank devisa antara lain dapat melaksanakan jasa yang berhubungan dengan seluruh mata uang asing atau jasa bank ke luar negeri, sedangkan bank non devisa tidak. (Kasmir, 2011). 


\subsection{Kinerja Perbankan}

Penilaian kinerja perbankan menjadi sangat penting dilakukan karena operasi perbankan sangat peka terhadap maju mundurnya perekonomian suatu negara. Kinerja perbankan dapat dinilai dengan pendekatan analisa rasio keuangan. Tingkat kesehatan bank diatur oleh Bank Indonesia dalam Surat Edaran Bank Indonesia Nomor 13/5/DPNP 8 Februari 2011 kepada semua bank umum yang melaksanakan kegiatan usaha secara konvensional perihal sistem penilaian tingkat kesehatan bank umum dan Peraturan Bank Indonesia Nomor 13/ 1 /PBI/2011 tentang sistem penilaian tingkat kesehatan bank umum, bank wajib melakukan penilaian tingkat kesehatan bank secara triwulan. Apabila diperlukan Bank Indonesia meminta hasil penilaian tingkat kesehatan bank tersebut secara berkala dan sewaktu-waktu untuk posisi penilaian tersebut terutama untuk menguji ketepatan dan kecukupan hasil analisis bank.

Penilaian Tingkat Kesehatan Bank mencakup penilaian terhadap faktor-faktor sebagai berikut:

a. permodalan (capital);

b. kualitas aset (asset quality);

c. manajemen (management);

d. rentabilitas (earning);

e. likuiditas (liquidity); dan

f. sensitivitas terhadap risiko pasar (sensitivity to market risk).

\subsection{Laporan Keuangan Perbankan}

Undang-undang Nomor 7 tahun 1992 tentang perbankan mendefinisikan bank sebagai badan usaha yang menghimpun dana dari masyarakat dalam bentuk simpanan dan menyalurkannya kepada strategis dalam pembangunan nasional, fungsi utamanya sebagai penghimpun dana dan penyalur dana dengan tujuan menunjang pelaksanaan pembangunan nasional dalam rangka meningkatkan banyak (Undangundang Perbankan, 1992). Dan sifat bank berbeda dengan bisnis perusahaan manufaktur maupun jenis perusahaan jasa lainnya.

Laporan keuangan merupakan suatu informasi yang menggambarkan kondisi suatu perusahaan, dimana selanjutnya itu akan menjadi suatu informasi yang menggambarkan tentang kinerja suatu perusahaan (Irham Fahmi, 2011). Aktiva bank pada umumnya sebagian besar merupakan aktiva likuid dan hanya sedikit aktiva tetap. Oleh karena itu, tingkat perputaran aktiva dan pasivanya sangat tinggi. Bisnis perbankan merupakan usaha yang sangat mengandalkan pada kepercayaan, yaitu kepercayaan masyarakat pengguna jasa bank.

Menurut ketentuan Bank Indonesia (1997) setiap bank harus menyajikan laporan keuangan seperti disebut di atas, setiap bank diwajibkan menyampaikan beberapa jenis laporan lainnya untuk disampaikan kepada BI. Laporan lainnya tersebut antara lain :

1. Laporan Mingguan

1. Giro wajib minimum yang mencakup, dana pihak ketiga rupiah / valuta asing per bank dan posisi pos-pos tertentu neraca rupiah dan valuta asing per bank.

2. Laporan keuntungan / kerugian transaksi derivative

3. Laporan posisi devisa netto (PDN)

2. Laporan Bulanan

a. Laporan beserta lampiran per kantor (LBU)

b. Laporan perkreditan bank umum per kantor ( LPBU)

c. Laporan pelanggaran batas maksimal pemberian kredit (BMPK)

3. Laporan Triwulanan, berupa laporan realisasi perkreditan bank terhadap rencana kerja bank.

4. Laporan Semesteran

a. Laporan dewan komisaris terhadap pelaksanaan rencana kerja bank

b. Laporan keuangan publikasi di surat kabar berbahasa Indonesia 
c. Laporan dewan audit tentang hasil kinerja audit intern yang telah dilakukan.

5. Laporan Tahunan

a. Laporan tahunan yang diaudit oleh akuntan public yang terdaftar di BI yang disertai dengan surat komentar dari akuntan public.

b. Laporan realisasi rencana kerja bank

6. Laporan lainnya

a. Kerugian transaksi derivative yang melebihi $10 \%$ dari modal bank beserta tindakan yang akan dilakukan untuk mengatasi selambat-lambatnya pada hari kerja berikutnya.

b. Laporan khusus mengenai setiap temuan audit yang diperkirakan dapat mengganggu kelangsungan usaha bank yang ditandatangani direktur utama dan ketua dewan audit selambat-lambatnya 15 hari kerja sejak adanya temuan audit.

c. Laporan atas setiap penyalahguanaan yang dilakukan melalui sarana teknologi sistem informasi.

d. Laporan pelaksanaan dan pokok-pokok hasil audit intern, ditanda tangani oleh direktur utama dan ketua dewan audit selambat-lambatnya 2 bulan setelah akhir Juni dan akhir Desember.

\subsection{Analisis Rasio Keuangan}

Rasio keuangan sangat penting gunanya untuk melakukan analisa terhadap kondisi keuangan perusahaan. Analisis rasio keuangan adalah metode analisis untuk mengetahui hubungan dari pos-pos tertentu dalam neraca atau laporan laba rugi secara individu ataupun secara kombinasi dari kedua laporan tersebut (Munawir,2002). Analisis rasio keuangan merupakan instrumen analisis prestasi perusahaan yang menjelaskan berbagai hubungan dan indikator keuangan yang ditujukan untuk menunjukan perubahan dalam kondisi keuangan atau prestasi operasi di masa lalu dan membantu menggambarkan trend pola perubahan tersebut, untuk kemudian menunjukan resiko dan peluang yang melekat pada perusahaan yang bersangkutan (Warsidi dan Bamabang).

\subsection{Return On Assets (ROA)}

ROA merupakan kemampuan dari modal yang diinvestasikan ke dalam seluruh aktiva perusahaan untuk menghasilkan keuntungan. ROA menggunakan laba sebagai salah satu cara untuk menilai efektivitas dalam penggunaan aktiva perusahaan dalam menghasilkan laba. Semakin tinggi laba yang dihasilkan, maka semakin tinggi pula ROA, hal itu berarti bahwa perusahaan semakin efektif dalam penggunaan aktiva untuk menghasilkan keuntungan.

ROA dihitung berdasarkan perbandingan laba sebelum pajak dan rata-rata total assets. Dalam penelitian ini ROA digunakan sebagai indikator performance atau kinerja bank. ROA menunjukkan efektivitas perusahaan dalam menghasilkan keuntungan dengan mengoptimalkan asset yang dimiliki. Semakin tinggi ROA maka menunjukkan semakin efektif perusahaan tersebut, karena besarnya ROA dipengaruhi oleh besarnya laba yang dihasilkan perusahaan.

\subsection{Capital Adequacy Ratio (CAR)}

CAR merupakan salah satu indikator kesehatan permodalan bank. Penilaian permodalan merupakan penilaian terhadap kecukupan modal bank untuk mengcover eksposur resiko saat ini dan mengantisipasi eksopur resiko dimasa yang akan datang. CAR menunjukan seberapa besar modal bank telah memadai untuk menunjang kebutuhannya dan sebagai dasar untuk menilai prospek lanjutan usaha bank besangkutan. Semakin besar CAR makan akan semakin besar daya tahan bank yang bersangkutan dalam menghadapi penyusutan nilai harta bank yang timbul karena adanya harta yang bermasalah.

\subsection{Biaya Operasi Dibanding Dengan Pendapatan Operasi (BOPO)}

BOPO merupakan rasio antara biaya operasi terhadap pendapatan operasi. Biaya operasi merupakan biaya yang dikeluarkan oleh bank dalam rangka menjalankan aktivitas usaha utamanya seperti biaya bunga, biaya pemasaran, biaya tenaga kerja dan biaya operasi lainnya. Pendapatan operasi merupakan pendapatan utama bank yaitu pendapatan yang diperoleh dari penempatan dana dalam bentuk 
kredit dan pendapatan operasi lainnya. Semakin kecil BOPO menunjukkan semakin efisien bank dalam menjalankan aktivitas usahanya. Menurut ketentuan Bank Indonesia efisiensi operasi diukur dengan BOPO.

\subsection{Non Performing Loan (NPL)}

NPL merupakan salah satu indikator kesehatan kualitas aset bank. Menurut Peraturan Bank Indonesia Nomor: 6/10/PBI/2004 tanggal 12 April 2004 tentang sistem penilaian tingkat kesehatan bank umum, semakin tinggi nilai NPL (diatas 5\%) maka bank tersebut tidak sehat. NPL yang tinggi menyebabkan menurunnya laba yang akan diterima oleh bank. Yang dimaksud dengan NPL adalah debitur atau kelompok debitur yang masuk dalam golongan 3, 4, 5 dari 5 golongan kredit yaitu debitur yang kurang lancar, diragukan dan macet. Salah satu resiko yang muncul akibat semakin kompleknya kegiatan perbankan adalah munculnya non performing loan (NPL) yang semakin besar. Semakin besar skala operasi suatu bank maka aspek pengawasan terhadap kegiatan operasi semakin menurun, sehingga mengakibatkan NPL semakin besar atau resiko kredit semakin besar.

\section{METODE PENELITIAN}

\subsection{Jenis Data dan Sumber Data}

\subsubsection{Jenis Data}

Data adalah sekumpulan informasi yang diperlukan untuk pengambilan keputusan (Kuncoro 2008). Data diperoleh dengan mengukur nilai satu atau lebih variabel dalam sampel (atau populasi). Menurut Kuncoro (2008) jenis data dapat diklasifikasikan menjadi dua golongan, yaitu:

1. Data kuantitatif: data yang disajikan dan diukur dalam suatu skala numerik atau dalam bentuk angka-angka. Data kuantitatif dalam penelitian ini berupa data jumlah CAR, BOPO dan NPL yang langsung diperoleh dari laporan keuangan publikasi BI, IDX dan info bank 2011.

2. Data kualitatif: data yang bersifat deskriptif atau berbentuk uraian atau penjelasan serta tidak dapat diukur dalam skala numerik.

\subsubsection{Sumber Data}

Yang menjadi sumber data dalam penelitian ini adalah Data sekunder : data yang diperoleh dari luar badan usaha (pihak eksternal perusahaan). Data sekunder berupa data laporan keuangan publikasi BI tahun 2008-2010 yang meliputi data Capital Adequacy Ratio (CAR), BOPO dan Non Performing Loan (NPL). Selain itu juga data sekunder dalam penelitian ini diperoleh dari berbagai macam buku, jurnal dan sumber lain yang berhubungan dengan kategori data eksternal.

\subsection{Teknik Pengumpulan Data}

Di dalam melengkapi hasil penelitian ini, maka penulis melakukan pengumpulan data dengan cara sebagai berikut :

1. Metode pengumpulan data yang digunakan dengan cara non participant observation, yaitu mencatat atau mengcopy data yang tercantum dalam "Rating 120 Bank Versi Infobank 2010" data dari Infobank tersebut dipublikasikan dalam Infobank No. 387 Juni 2010, data laporan keuangan publikasi BI tahun 2008-2010 dan data lain bersumber dari IDX.

2. Studi Kepustakaan, yaitu suatu metode untuk mendapatkan informasi dari teori-teori dengan cara mempelajari serta mencatat dari buku-buku literatur, majalah, jurnal, serta bahan-bahan informasi lainnya yang berhubungan dengan materi yang dibahas oleh penulis, yang kesemuanya itu diperoleh langsung dari perpustakaan Fakultas Ekonomi Universitas Sam Ratulangi Manado, perpustakaan PPA (Pendidikan Profesi Akuntan) yang juga ada di Fakultas Ekonomi Universitas Sam Ratulangi Manado, serta melalui jaringan internet dengan penelusuran Google dan Yahoo. 


\subsection{Populasi dan Sampel}

Populasi adalah wilayah generalisasi yang terdiri atas objek atau subjek yang mempunyai kuantitas dan karakteristik tertentu yang ditetapkan oleh peneliti untuk dipelajari dan kemudian ditarik kesimpulannya. Sebagai suatu populasi kelompok subyek ini harus memiliki ciri - ciri atau karakteristik bersama yang membedakan dari kelompok subyek yang lain (Sugiyono 2008).

Populasi dalam penelitian ini adalah bank umum yang beroperasi di Indonesia pada tahun 20082010 yang terdaftar di BEI sebanyak 28 bank. Oleh karena daftar bank pada tahun 2008-2010 berbeda, maka penelitian dilakukan terhadap seluruh 22 bank yang tetap terdaftar di BEI dalam kurun waktu 20082010.

Sampel penelitian diambil secara purposive sample dimana sampel digunakan apabila memenuhi kriteria sebagai berikut :

1. Tersedia data laporan keuangan dalam kurun waktu penelitian (periode tahun 2008-2010).

2. Bank yang diteliti masih beroperasi dalam kurun waktu penelitian yaitu tahun 2008-2010. Berdasarkan kriteria diatas maka jumlah sampel yang dapat digunakan adalah 22 bank.

\subsection{Definisi Operasional dan Pengukuran Variabel}

Variable-variabel yang digunakan dalam penelitian ini adalah :

1. Variabel dependen berupa kinerja perbankan yang diukur dengan Return On Assets (ROA). ROA pada bentuk yang paling sederhana dihitung sebagai laba dibagi aktiva. ROA dapatdipisahkan menjadi komponen yang memiliki makna relatif terhadap penjualan. Hal inidilakukan karena rasio komponen ini berguna bagi analisis kinerja perusahaan. Penjualanmerupakan kriteria penting untuk menilai profitabilitas perusahaan dan merupakan indikator utama atas aktivitas perusahaan. ROA yang digunakan dalam penelitian mengacu pada Surat Edaran Bank Indonesia Nomor 6/23/DPNP tanggal 31 Mei 2004 dimana didefinisikan sebagai berikut :

$$
\text { ROA }=\frac{\text { Laba Sebelum Pajak }}{\text { Rata }- \text { rata Total Aset }}
$$

2. Variabel independent berupa rasio-rasio keuangan antara lain CAR, BOPO, dan NPL. Masingmasing variabel didefinisikan sebagai berikut :
a. Capital Adequancy Ratio (CAR)
Modal
$\mathbf{C A R}=$
Aktiva Tertimbang Menurut Resiko

\section{b. Biaya Operasi dibanding dengan Pendapatan Operasi (BOPO) \\ BOPO = $\underline{\text { Total Beban Operasional }}$ \\ Total Pendapatan Operasional}

\section{c. Non Performing Loan (NPL) \\ NPL $=\quad \underline{\text { Kredit yang Bermasalah }}$}

\subsection{Metode Analisis}

Sesuai dengan hipotesis yang dirumukan maka alat analisis yang digunakan adalah analisis regresi berganda dengan persamaan kuadrat terkecil (OLS). Adapun bentuk model yang digunakan dari model dasar penentuan ROA adalah sebagai berikut :

$$
\begin{aligned}
\mathbf{Y}=\boldsymbol{\alpha}+\boldsymbol{\beta}_{\mathbf{1}} \mathbf{X}_{\mathbf{1}} & +\boldsymbol{\beta}_{\mathbf{2}} \mathbf{X}_{\mathbf{2}}+\boldsymbol{\beta}_{\mathbf{3}} \mathbf{X}_{\mathbf{3}}+\boldsymbol{\varepsilon} \\
\text { Keterangan : } \mathrm{Y} & =\mathrm{ROA} \\
\beta_{1} & =\text { koefisien regresi untuk } \mathrm{X}_{1} \\
\beta_{2} & =\text { koefisien regresi untuk } X_{2}
\end{aligned}
$$




$$
\begin{aligned}
\beta_{3} & =\text { koefisien regresi untuk } X_{3} \\
X_{1} & =\text { CAR } \\
X_{2} & =\text { BOPO } \\
X_{3} & =\text { NPL } \\
\varepsilon & =\text { error sampling }
\end{aligned}
$$

\section{HASIL PENELITIAN DAN PEMBAHASAN}

\subsection{Deskripsi Objek Penelitian}

Berdasarkan pengumpulan data dan jumlah perusahaan yang terdaftar di BEI periode 2008-2010 pada periode ini terdapat 28 bank, akan tetapi setelah dilakukan purposive sampling, maka sampel yang layak digunakan (memenuhi kriteria) dalam penelitian ini ada 22 buah perusahaan perbankan yang tercatat di BEI. Perusahaan perbankan, dari data 3 tahun periode maka jumlahnya adalah 66 bank.

\subsection{Hasil Penelitian}

\subsubsection{Pengujian Asumsi Klasik}

Pengujian asumsi klasik dilakukan untuk mengetahui hubungan antara variabel bebas. Berdasarkan hasil pengolahan data yang menggunakan program aplikasi SPSS versi 20, maka diperoleh interpretasi dari hasil pengujian asumsi klasik sebagai berikut:

1. Uji Normalitas

Uji normalitas bertujuan untuk menguji apakah dalam model regresi variabel terikat dan variabel bebas keduanya mempunyai distribusi normal atau tidak (Ghozali : 2007). Penelitian ini mengunakan pendekatan grafik Normal $P-P$ of regression standardized residual untuk menguji normalitas data. Jika data menyebar disekitar garis diagonal pada grafik Normal $P-P$ of regression standardized residual dan mengikuti arah garis diagonal tersebut, maka model regresi memenuhi asumsi normalitas, tetapi jika sebaliknya data menyebar jauh berarti tidak memenuhi asumsi normalitas tersebut (Santoso : 2009).

Tabel 4.1

Hasil Pengujian Normalitas

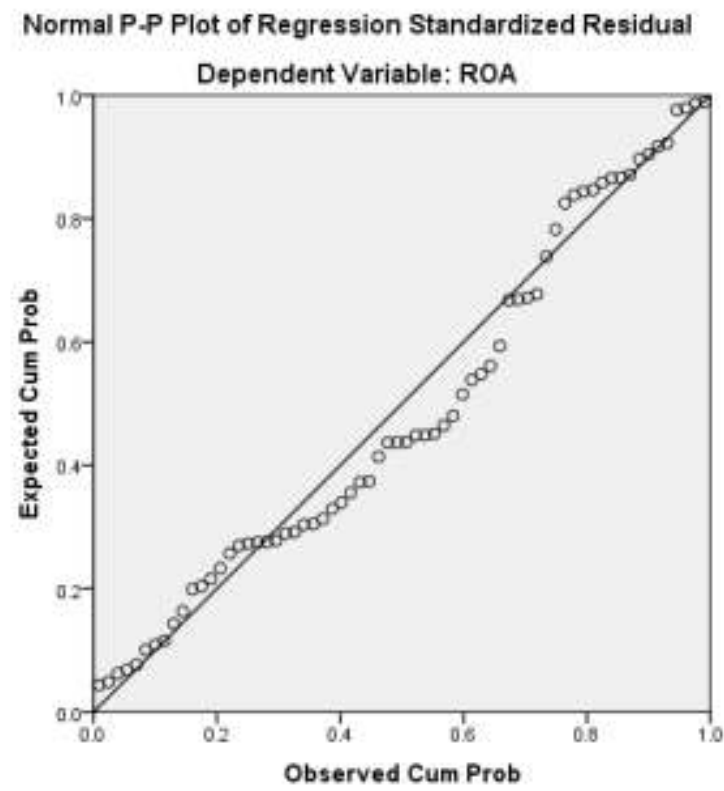

Sumber: Data olahan, 2012 
Dari gambar 4.1 diketahui bahwa data menyebar disekitar garis diagonal pada grafik Normal P-P of regression standardized residual dan mengikuti arah garis diagonal tersebut, maka model regresi memenuhi asumsi normalitas

2. Uji Multikolinearitas

Suatu model regresi dinyatakan bebas dari multikolinearitas jika mempunyai nilai tolerance lebih dari 0,10 dan nilai Variance Inflation Factor (VIF) kurang dari 10.

Tabel 4.2

Hasil Pengujian Multikolinearitas

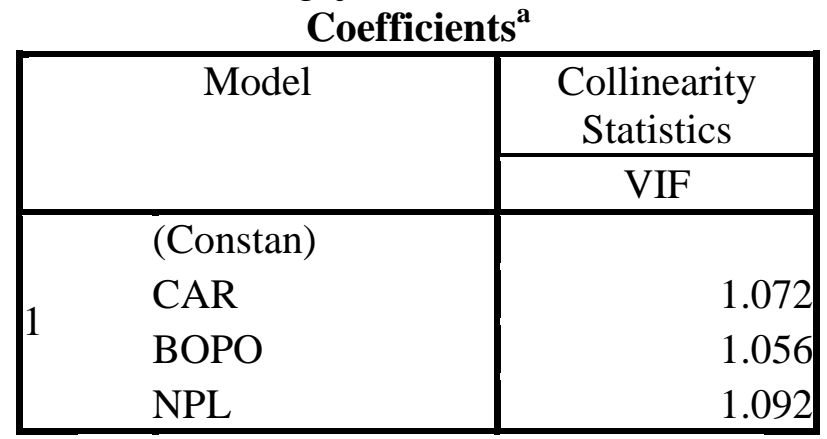

a. Dependent Variable: ROA

Dari Tabel 4.1 diketahui bahwa semua variabel bebas mempunyai nilai tolerance lebih dari 0,10 dan nilai VIF kurang dari 10. Hal ini berarti bahwa model regresi linear dalam penelitian ini bebas dari multikolinearitas.

3. Uji Heteroskedastisitas

Gambar 4.2

Hasil Pengujian Heteroskedastisitas

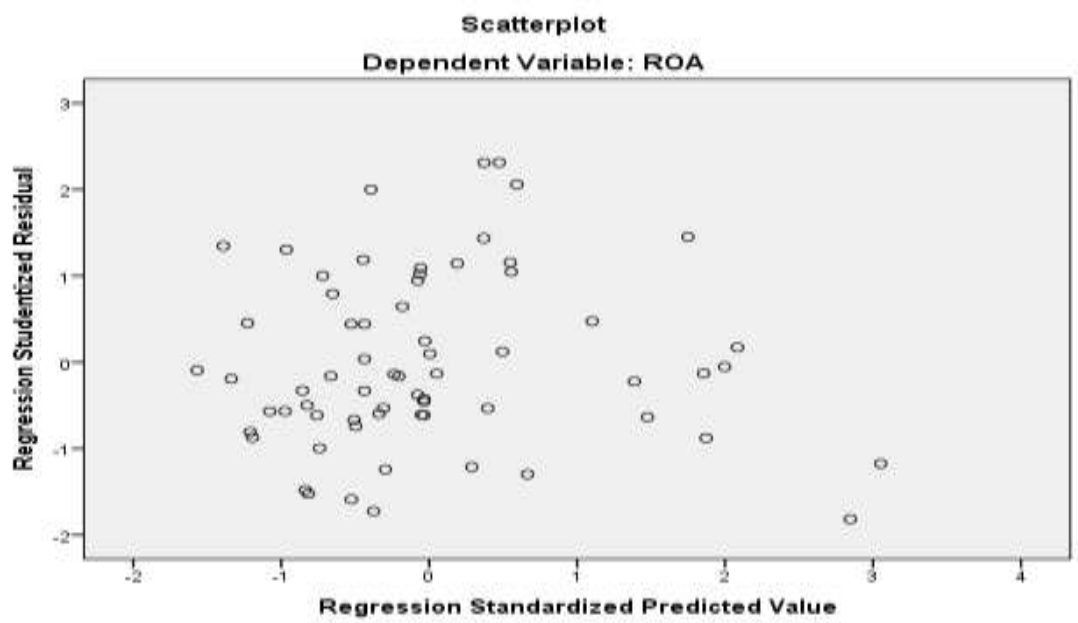

Sumber: Data olahan, 2010

Untuk mendeteksi ada tidaknya heterokedastisitas dalam penelitian ini, dapat dilihat melalui analisis grafik Scatterplot pada Gambar 4.2. Dari gafik Scatterplot pada Gambar 4.2 terlihat bahwa titiktitik cukup menyebar di atas dan di bawah angka 0 (nol), sehingga dapat disimpulkan bahwa tidak terjadi heteroskedastisitas pada model regresi dalam penelitian ini. 
4. Uji Autokorelasi

Model regresi yang baik seharusnya bebas dari outokorelasi. Deteksi adanya autokorelasi yaitu dengan melihat nilai Durbin Watson (DW) pada Tabel 5.2. Nilai Durbin-Watson adalah 1,581, yang berarti berada di antara -2 dan +2 atau $-2<1,581<+2$. Maka ini berarti model regresi dalam penelitian ini bebas dari autokorelasi.

Tabel 4.4 Hasil Pengujian Autokorelasi Model Summary ${ }^{b}$

\begin{tabular}{|l|r|r|r|r|r|}
\hline Model & \multicolumn{1}{|c|}{$\mathrm{R}$} & R Square & $\begin{array}{c}\text { Adjusted R } \\
\text { Square }\end{array}$ & $\begin{array}{c}\text { Std. Error of } \\
\text { the Estimate }\end{array}$ & $\begin{array}{c}\text { Durbin- } \\
\text { Watson }\end{array}$ \\
\hline 1 & $.361^{\mathrm{a}}$ & .130 & .088 & 1.10389 & 1.581 \\
\hline
\end{tabular}

Sumber: Data olahan, 2012

Setelah dilakukan pengujian asumsi klasik, yaitu uji normalitas, uji multikolinearitas, uji heteroskedastisitas, dan uji autokorelasi, maka terbukti bahwa hasil analisa regresi dalam penelitian ini telah bebas dari gangguan normalitas, multikolinearitas, heteroskedastisitas, dan autokorelasi.

\subsubsection{Koefisien Korelasi dan Koefisien Determinasi}

Tabel 4.5 Hasil Koefisien Korelasi dan Koefisien Determinasi Model Summary ${ }^{\mathrm{b}}$

\begin{tabular}{|c|c|c|c|c|c|}
\hline Model & $\mathrm{R}$ & R Square & $\begin{array}{c}\text { Adjusted R } \\
\text { Square }\end{array}$ & $\begin{array}{l}\text { Std. Error of } \\
\text { the Estimate }\end{array}$ & $\begin{array}{l}\text { Durbin- } \\
\text { Watson }\end{array}$ \\
\hline 1 & $.361^{\mathrm{a}}$ & .130 & .088 & 1.10389 & 1.581 \\
\hline
\end{tabular}

a. Predictors: (Constant), NPL, BOPO, CAR

b. Dependent Variable: ROA

Sumber: Data Olahan, 2012

Pada Tabel 4.3 dapat dilihat nilai koefisien korelasi (R) adalah sebesar 0,361. Hal ini menunjukkan bahwa ketiga variabel bebas yaitu $N P L, B O P O$ dan $C A R$ secara bersama-sama mempunyai hubungan yang lemah positif terhadap $R O A$. Hasil perhitungan koefisien determinasi dalam penelitian ini dapat dilihat pada Tabel 4.3. Berdasarkan output SPSS pada Tabel 4.3 tampak bahwa nilai koefisien determinasi adalah 0,130. Hal ini menunjukkan bahwa besarnya pengaruh variabel bebas, yaitu $N P L, B O P O$ dan $C A R$ terhadap variabel terikat yaitu $R O A$ yang dapat diterangkan oleh model persamaan dalam penelitian ini adalah sebesar $13 \%$, sedangkan sisanya sebesar $87 \%$ diterangkan oleh faktor-faktor lain yang tidak dimasukkan dalam model regresi.

\subsubsection{Analisis Regresi Berganda}

Tabel 4.6 Hasil Perhitungan Regresi Parsial

Coefficient

\begin{tabular}{|c|c|c|c|c|c|c|}
\hline \multirow{2}{*}{\multicolumn{2}{|c|}{ Model }} & \multicolumn{2}{|c|}{$\begin{array}{l}\text { Unstandardized } \\
\text { Coefficients }\end{array}$} & $\begin{array}{l}\text { Standardized } \\
\text { Coefficients }\end{array}$ & \multirow[t]{2}{*}{$\mathrm{t}$} & \multirow[t]{2}{*}{ Sig. } \\
\hline & & B & Std. Error & Beta & & \\
\hline \multirow{4}{*}{1} & (Constant) & 3.917 & .777 & & 5.044 & .000 \\
\hline & CAR & -.008 & .023 & -.046 & -.371 & .712 \\
\hline & BOPO & -.023 & .008 & -.370 & -3.039 & .003 \\
\hline & NPL & .078 & .108 & .090 & .729 & .469 \\
\hline
\end{tabular}

a. Dependent Variable: ROA

Sumber: Data Olahan, 2012 
Dari hasil analisis dalam tabel diperoleh persamaan regresi linier berganda sebagai berikut :

$$
\begin{aligned}
& Y=b_{0}+b_{1} X_{1}+b_{2} X_{2}+b_{3} X_{3}+e \\
& Y=3,917-0.008 X_{1}-0,023 X_{2}+0,078 X_{3}
\end{aligned}
$$

Dari persamaan regresi linier berganda di atas, dapat menginformasikan bahwa

- Nilai konstan sebesar 3,917 artinya jika variabel Capital Adequacy Ratio (CAR), dan Biaya Operasi di Banding Pendapatan Operasi (BOPO), dan Non Performing Loans (NPL) dianggap konstan, maka Return on Asset (ROA) akan sebesar 3,917.

- Koefisien $\mathrm{X}_{1}$ Capital Adequacy Ratio (CAR) sebesar - 0.008 yang berarti setiap penurunan variabel CAR sebesar satu persen maka akan meningkatkan Return on Asset (ROA) sebesar 0,008 $\%$ dengan asumsi faktor-faktor lain dianggap tetap (citeris paribus).

- Koefisien $\mathrm{X}_{2}$ Biaya Operasi di Banding Pendapatan Operasi (BOPO) sebesar - 0,023 yang berarti setiap penurunan Variabel BOPO $\left(\mathrm{X}_{2}\right)$ sebesar satu persen maka akan meningkatkan Kinerja Keuangan Bank yang diproksikan dengan ROA sebesar $0.023 \%$ dengan asumsi faktor-faktor lain dianggap tetap (citeris paribus).

- Koefisien $\mathrm{X}_{3}$ Non Performing Loans (NPL) sebesar 0,078 yang berarti setiap kenaikan Variabel NPL $\left(\mathrm{X}_{3}\right)$ sebesar satu persen maka akan meningkatkan Return on Asset (ROA) sebesar 0,078\% dengan asumsi faktor-faktor lain dianggap tetap (citeris paribus).

\subsubsection{Pengujian Hipotesis}

\section{a. Uji t (Uji Parsial)}

Uji $\mathrm{t}$ adalah untuk menguji pengaruh variabel bebas secara parsial atau sendiri-sendiri, untuk mengetahui kemampuan dari masing-masing variabel dalam mempengaruhi variabel dependent, dengan menganggap variabel lain konstan/tetap.

Tabel 4.7 Hasil Perhitungan Uji t

\begin{tabular}{|c|c|c|c|c|c|c|}
\hline \multirow{2}{*}{\multicolumn{2}{|c|}{ Model }} & \multicolumn{2}{|c|}{$\begin{array}{l}\text { Unstandardized } \\
\text { Coefficients }\end{array}$} & \multirow{2}{*}{$\begin{array}{c}\begin{array}{l}\text { Standardized } \\
\text { Coefficients }\end{array} \\
\text { Beta }\end{array}$} & \multirow[t]{2}{*}{$\mathrm{t}$} & \multirow[t]{2}{*}{ Sig. } \\
\hline & & $\mathrm{B}$ & Std. Error & & & \\
\hline \multirow{4}{*}{1} & (Constant) & 3.917 & .777 & & 5.044 & .000 \\
\hline & CAR & -.008 & .023 & -.046 & -.371 & .712 \\
\hline & BOPO & -.023 & .008 & -.370 & -3.039 & .003 \\
\hline & NPL & .078 & .108 & .090 & .729 & .469 \\
\hline
\end{tabular}

Coefficients

a. Dependent Variable: ROA

Sumber: Data Olahan, 2012

Nilai $t_{\text {tabel }}$ dengan jumlah sampel $(n)=66$,jumlah variabel $(\mathrm{k})=4$, taraf signifikan $\alpha=0,05 / 2=$ 0,025 (uji 2 sisi); degree of freedom (df) $=\mathrm{n}-\mathrm{k}=66-4=62$ sehingga diperoleh nilai $\mathrm{t}_{\text {tabel }}$ sebesar $\pm 2,29$

Berdasarkan Tabel 4.6 diperoleh nilai $\mathrm{t}$ hitung untuk CAR $\left(\mathrm{X}_{1}\right)$ sebesar $-0,371<$ dari nilai $\mathrm{t}$ tabel sebesar 2,29 dan nilai signifikansi $\mathrm{P}=0,712>\alpha=0.05$, maka $_{\mathrm{o} 1}$ diterima dan $\mathrm{H}_{\mathrm{a} 1}$ ditolak, artinya variable CAR $\left(\mathrm{X}_{1}\right)$ berpengaruh tidak signifikan terhadap Return on Asset (ROA) dan terdapat hubungan tidak searah.

Nilai $t_{\text {hitung }} X_{2}$ sebesar 3,039 > dari nilai $t_{\text {tabel }}$ sebesar 2,29, dan nilai signifikansi $P=0,003>\alpha=$ 0.05, maka $\mathrm{H}_{\mathrm{o} 2}$ ditolak, yang berarti $\mathrm{H}_{\mathrm{a} 2}$ diterima artinya variable $\mathrm{BOPO}$ berpengaruh positif dan signifikan terhadap Return on Asset (ROA). 
Nilai $\mathrm{t}_{\text {hitung }} \mathrm{X}_{3}=0,729$ sebesar $0.551<$ dari nilai $\mathrm{t}_{\text {tabel }}$ sebesar 2,29 dan nilai signifikansi $\mathrm{P}=0,469$ $>\alpha=0.05$, maka $\mathrm{H}_{03}$ diterima dan $\mathrm{H}_{\mathrm{a} 3}$ ditolak, artinya variable NPL $\left(\mathrm{X}_{1}\right)$ berpengaruh tidak signifikan terhadap Return on Asset (ROA).

\section{b.Uji F (Uji Simultan)}

Uji statistik F pada dasarnya menunjukan apakah semua variabel independen yang dimasukan dalam model mempunyai pengaruh secara bersama-sama terhadap variabel dependennya.

Tabel 4.8 Hasil Perhitungan Uji F

ANOVA ${ }^{\mathrm{a}}$

\begin{tabular}{|rl|r|r|r|r|r|}
\hline \multicolumn{1}{|l|}{ Model } & \multicolumn{1}{c|}{$\begin{array}{c}\text { Sum of } \\
\text { Squares }\end{array}$} & df & $\begin{array}{c}\text { Mean } \\
\text { Square }\end{array}$ & F & Sig. \\
\hline \multirow{2}{*}{1} & Regression & 11.311 & 3 & 3.770 & 3.094 & $.033^{\mathrm{b}}$ \\
& Residual & 75.551 & 62 & 1.219 & & \\
& Total & 86.862 & 65 & & & \\
\hline
\end{tabular}

a. Dependent Variable: ROA

b. Predictors: (Constant), NPL, BOPO, CAR

Sumber: Data Olahan, 2012

Berdasarkan hasil uji $\mathrm{F}$ yang dapat dilihat pada Tabel 4.7, diperoleh $\mathrm{F}$ hitung sebesar 3,904 dengan tingkat signifikansi atau probabilitas sebesar $0,033>\alpha=0,05$, maka $_{4}$ diterima artinya Capital Adequacy Ratio (CAR), dan Biaya Operasi di Banding Pendapatan Operasi (BOPO), dan Non Performing Loans (NPL) tidak berpengaruh signifikan terhadap Kinerja keuangan Bank yang diproksikan dengan ROA.

\subsection{Pembahasan}

Berdasarkan hasil uji $\mathrm{F}$ diketahui bahwa kinerja bank yang diproksikan dengan ROA dapat dipengaruhi signifikan secara bersama-sama oleh variabel-variabel CAR, NPL, dan BOPO dengan nilai $\mathrm{F}$ hitung sebesar 3,904 dengan nilai signfikansi 0,033. Dari nilai adjusted $R$ square, didapatkan bahwa $13 \%$ variabel ROA dapat dijelaskan oleh variasi dari 3 variabel.

Hasil uji regresi menunjukkan tidak adanya pengaruh yang signifikan dan mempunyai hubungan yang negatif variable CAR terhadap kemampuan pengembalian asset (ROA) dengan nilai 0,712. Hasil penelitian ini menunjukkan bahwa semakin besar Capital Adequacy Ratio (CAR) maka ROA yang diperoleh bank akan semakin berkurang. Semakin besar Capital Adequacy Ratio (CAR) maka semakin rendah kemampuan pengembalian asset (ROA) bank, menurunnya CAR tersebut disebabkan terkikisnya modal akibat negatif spread dan peningkatan aset yang tidak diimbangi dengan penambahan modal. Rendahnya CAR bisa menyebabkan turunnya kepercayaan masyarakat yang pada akhirnya dapat menurunkan Kinerja Bank yang ditunjukkan oleh ROA.

Hasil penelitian ini sesuai dengan hasil dari penelitian Mawardi (2005) menunjukkan bahwa CAR tidak berpengaruh terhadap ROA yang merupakan proksi dari kinerja keuangan bank umum. Hal ini terjadi karena peraturan Bank Indonesia yang mensyaratkan CAR minimal sebesar 8\% mengakibatkan bank-bank selalu berusaha menjaga agar CAR yang dimiliki sesuai dengan ketentuan. Namun bank cenderung menjaga CAR-nya tidak lebih dari $8 \%$ karena ini berarti pemborosan. Hal tersebut juga dapat terjadi karena bank belum dapat melempar kredit sesuai dengan yang diharapkan atau belum optimal. Berbeda dengan hasil dari penelitian Desfian (2005) yang menyatakan bahwa CAR berpengaruh positif terhadap ROA. Suyono (2005) menyatakan bahwa perubahan CAR berpengaruh positif dan signifkan terhadap ROA. Modal bank merupakan "engine" dari pada kegiatan bank, jika kapasitas mesinnya terbatas maka sulit bagi bank tersebut untuk meningkatkan kapasitas kegiatan usahanya khususnya dalam penyaluran kredit. CAR dibawah $8 \%$ tidak mempunyai peluang untuk memberikan kredit. Padahal 
kegiatan utama bank adalah menghimpun dana dan menyalurkannya kembali dalam bentuk kredit. Dengan CAR yang cukup atau memenuhi kententuan, Selain itu, semakin tinggi permodalan bank maka bank dapat melakukan ekspansi usahanya dengan lebih aman. Adanya ekspansi usaha yang pada akhirnya akan mempengarui kinerja keuangan bank tersebut. Pendanaan yang efisien akan terjadi bila perusahaan mempunyai capital yang optimal.

Hasil uji regresi menunjukkan bahwa variabel BOPO berpengaruh signifikan terhadap ROA dengan nilai signifikasi 0,003 yang berada dibawah 0,05. Hal ini menunjukkan Variabel BOPO berpengaruh signifikan terhadap ROA perusahaan, hal ini menandakan bahwa dengan meningkatnya BOPO pada perusahaan perbankan menandakan perusahaan lebih banyak mengeluarkan biaya operasional dalam menghasilkan laba. Kondisi ini juga menandakan bahwa perusahaan yang menghasilkan laba besar tidak efisien dalam melakukan operasionalnya sehingga BOPO berpengaruh negatif terhadap ROA. Berpengaruhnya BOPO terhadap ROA didukung oleh hasil penelitian yang dilakukan oleh Suyono (2005). Disamping itu BOPO juga merupakan variabel yang mampu membedakan bank yang mempunyai ROA diatas rata-rata maupun bank yang mempunyai ROA dibawah rata-rata. Dalam pengelolaan aktivitas operasional bank yang efisien dengan memperkecil biaya operasional bank akan sangat mempengaruhi besarnya tingkat keuntungan bank yang tercermin dalam ROA sebagai indikator yang mencerminkan efektivitas perusahaan dalam menghasilkan laba dengan memanfaatkan keseluruhan aktiva yang dimiliki.

Hasil uji regresi menunjukkan bahwa variabel NPL tidak berpengaruh signifikan terhadap ROA dengan nilai signifikasi 0,469 yang berada diatas 0,05. Hal ini menunjukkan bahwa tingkat pengembalian kredit bank tidak mempunyai pengaruh yang signifikan terhadap besar kecilnya ROA bank. Dalam memberikan kredit, akan meningkatkan piutang bank yang masuk kelompok asset untuk itu bank harus melakukan analisis terhadap kemampuan debitur dalam memenuhi kewajiban mereka kepada bank. Bank harus melakukan peninjauan, penilaian, dan pengikatan terhadap agunan untuk memperkecil risiko kredit atau gagal bayar debitur. Jadi apabila debitur tersebut tidak memenuhi kewajiban mereka kepada bank maka pihak bank dapat menjual agunan debitur untuk menutupi semua tunggakan atau melunasi pinjaman debitur tersebut.

Krisis global di Amerika, Australia, Eropa, dan Asia pada tahun 2008 berdampak negative terhadap kondisi bursa dan pasar keuangan Amerika Serikat. Banyak diantara lembaga-lembaga keuangan yang sudah berusia lebih dari 100 tahun harus meminta penyelamatan keuangan mereka apabila tidak mau gulung tikar. Sedangkan di Indonesia sendiri pemerintah berupaya memperluas jenis aset milik bank yang boleh diagunkan kepada BI, yang tadinya hanya meliputi aset kualitas tinggi. Hal ini ditujukan agar mempermudah bank dalam mengatasi kesulitan likuiditas, sehingga dapat memperoleh jumlah dana yang cukup dari BI.

Dari kejadian krisis global di Amerika pada tahun 2008 yang seharusnya jika NPL suatu bank naik maka kinerja bank akan menurun dan berpengaruh terhadap ROA bank, tapi yang tejadi pada tahun 2008 adalah sebaliknya karena saat itu jumlah kredit yang diberikan meningkat sehingga menambah biaya cadangan aktiva produktif yang pada akhirnya mempengaruhi ROA bank.

Hasil penelitian ini tidak sesuai dengan hasil penelitian Mawardi (2005) Non Performing Loan (NPL) berpengaruh terhadap ROA. NPL merupakan perbandingan total pinjaman bermasalah dibanding dengan total pinjaman diberikan pihak ketiga. Bank dapat menjalankan operasinya dengan baik jika mempunyai NPL dibawah 5\%. Kenaikan NPL yang semakin tinggi menyebabkan cadangan Penyisihan Penghapusan Aktiva Produktif (PPAP) yang ada tidak mencukupi sehingga pemacetan kredit tersebut harus diperhitungkan sebagai beban (biaya) yang langsung berpengaruh terhadap keuntungan bank dan karena keuntungan atau akumulasi keuntungan juga habis, maka harus dibebankan kepada modal. (Dunil, 2005). 


\section{KESIMPULAN DAN SARAN}

\subsection{Kesimpulan}

Berdasarkan hasil dan pembahasan, dapat ditarik beberapa kesimpulan sebagai berikut :

1. Berdasarkan nilai $R$ square sebesar 0,130 menunjukan bahwa variabel bebas NPL, BOPO dan CAR secara bersama-sama mempunyai hubungan yang lemah positif terhadap ROA. Hal ini berarti 13 persen ROA dipengaruhi oleh ketiga variabel bebas CAR, NPL dan BOPO. Sedangkan sisanya 87 persen dipengaruhi oleh sebab-sebab lain di luar model regresi.

2. Hasil nilai $F$ hitung sebesar 3,094 dengan $P$ value sebesar $0,033>\alpha=0,05$ yang menunjukkan bahwa variabel CAR, NPL, dan BOPO tidak berpengaruh signifikan terhadap kinerja keuangan Bank yang diproksikan dengan ROA.

3. Secara parsial variable CAR tidak berpengaruh terhadap ROA dilihat dari nilai t hitung sebesar 0,371 dengan tingkat signifikansi sebesar 0,712 yang berarti nilai $\mathrm{P}$ value lebih dari 0,05.

4. Variabel NPL secara parsial tidak berpengaruh terhadap ROA dilihat dari nilai $\mathrm{t}$ hitung sebesar 0,729 dengan tingkat signifikansi sebesar 0,469 yang berarti nilai $\mathrm{P}$ value lebih dari 0,05. Berdasarkan persamaan regresi menunjukan bahwa tingkat pengembalian kredit bank tidak mempunyai pengaruh yang signifikan terhadap besar kecilnya ROA bank. Bank dapat menjalankan operasinya dengan baik jika mempunyai NPL dibawah $5 \%$.

5. Variabel BOPO secara parsial berpengaruh signifikan terhadap ROA dilihat dari nilai t hitung sebesar - 3,039 dengan tingkat signifikansi sebesar 0,003 yang berarti nilai $\mathrm{P}$ value kurang dari 0,05. Hal ini menunjukkan Variabel BOPO berpengaruh signifikan terhadap ROA perusahaan, hal ini menandakan bahwa dengan meningkatnya BOPO pada perusahaan perbankan menandakan perusahaan lebih banyak mengeluarkan biaya operasional dalam menghasilkan laba. Kondisi ini juga menandakan bahwa perusahaan yang menghasilkan laba besar tidak efisien dalam melakukan operasionalnya sehingga BOPO berpengaruh negatif terhadap ROA.

\subsection{Saran}

Berdasarkan kesimpulan tersebut diatas, disusun sejumlah saran sebagai berikut :

1. Kinerja suatu perbankan dapat ditingkatkan dengan menganalisa setiap permasalahan atau resiko yang mungkin terjadi yang dapat menimbulkan kerugian bagi perbankan. Untuk itu bank harus mengerti dan mengenal resiko-resiko yang mungkin timbul dalam melaksanakan kegiatan usahanya. Untuk menjaga Non Performing Loan (NPL) kurang dari 5\% bank harus melakukan analisa 5C yaitu Character, Capasity, Capital, Condition, dan Colleteral. Untuk laba perbankan sebaiknnya bank menekan semaksimal mungkin biaya-biaya operasional serta meningkatkan pendapatan operasi sehingga dapat menambah laba operasi yang akhirnya meningkatkan ROA.

2. Saran untuk peneliti selanjutnya diharapkan dapat menambah variable independen lainnya yang dapat mengukur kinerja suatu perusahaan perbankan yang nantinya juga berpengaruh terhadap ROA, tentunya dengan mempertimbangkan segala keterbatasan yang ada dalam penelitian ini..

\section{DAFTAR PUSTAKA}

Irham Fahmi, 2011, Analisis Laporan Keuangan, Alfabeta, Bandung.

Ferry, N Idroes dan Sugiarto. 2006, Manajemen Resiko Perbankan, Graha Ilmu, Yogyakarta.

Kasmir,2011, Dasar-dasae Perbankan, PT RajaGrafindo Persada, Jakarta.

James, O Gill dan Moira Chatton, Memahami Laporan Keuangan.

Kasmir, 2003, Manajemen Perbankan, PT RajaGrafindo Persada, Jakarta.

Irham Fahmi, 2011, Analisis Kinerja Keuangan, Alfabeta, Bandung.

Masyud, H Ali, 2003, Manajemen Resiko, PT RajaGrafindo Persada, Jakarta.

Jopie Jusuf, 1993, Analisis Kredit Untik Account Officer, PT Gramedia Pustaka Utama, Jakarta. 
Kasmir, 2008, Analisis Laporan Keuangan, PT Rajagrafindo Persada, Jakarta.

Infobank 2011. Rating 120 Bank. InfoBank. No.387. Edisi Juni 2011.

Pedoman Akuntansi Perbankan Indonesia, 2008,

Rintistya Kurniadi, 2012, Pengaruh CAR, NIM, LDR Terhadap Return Saham Perusahaan Perbankan

Indonesia. Journal of Accounting Analysis, Vol 1, No. 1.

Asna, 2006, Analisis Pengaruh Rasio Keuangan Terhadap Return Saham Perbankan Yang Terdaftar

di Bursa Efek Jakarta. Journal Of Economic, Vol 2 No.3.

Mawardi, Wisnu, 2005, Analisis Faktor Faktor Yang Mempengaruhi Kinerja Keuangan Bank Umum di Indonesia (Studi Kasus pada Bank Umum Dengan Total Asset Kurang dari Satu Triliun), Jurnal Bisnis Strategi, Vol 14, No 1, Juli, pp 83-94 .

Peraturan Bank Indonesia No: 11/1/PBI/2009, Bank Umum.

Peraturan Bank Indonesia No. 13/ 1/PBI/2011, Sistem Penilaian Tingkat Kesehatan Bank Umum.

Surat Edaran Bank Indonesia Nomor 7/10/DPNP tanggal 31 Maret 2005 Laporan Keuangan Publikasi

Triwulanan dan Bulanan Bank Umum, Bank Indonesia, Jakarta

http://www.bi.co.id

http://www.idx.co.id

http://www.infobank.com 